\title{
Piñon-Juniper Woodland Use by Cattle in Relation to Weather and Animal Reproductive State
}

\author{
Christina M. Black Rubio, ${ }^{1}$ Andrés F. Cibils, ${ }^{2}$ Rachel L. Endecott, ${ }^{3}$ \\ Mark K. Petersen, ${ }^{4}$ and Kenneth G. Boykin ${ }^{5}$ \\ Authors are ${ }^{1}$ Program Director/Agricultural Agent, Hidalgo County Extension Office, Lordsburg, NM 88045, USA; ${ }^{2}$ Assistasnt Professor and ${ }^{4}$ Professor, \\ Department of Animal and Range Sciences, New Mexico State University, Las Cruces, NM 88003, USA; ${ }^{3}$ Beef Cattle Extension Specialist, Department of \\ Animal and Range Sciences, Montana State University, Miles City, MT 59301, USA; and ${ }^{5}$ Ecologist, Center for Applied Spatial Ecology, New Mexico \\ Cooperative Fish and Wildlife Research Unit, New Mexico State University, Las Cruces, NM 88003, USA.
}

\begin{abstract}
We conducted a study to determine the role of piñon-juniper (PJ) woodland in providing shelter for cattle at a site in central New Mexico. Positions of 16 cows, 8 pregnant or nursing (PN) and 8 nonpregnant-nonlactating (NPNL), grazing a PJ woodland-grass steppe mosaic were recorded every $5 \mathrm{~min}$ by Global Positioning System during late winter and early spring in 2004 and 2005 (eight different cows in each year). Hourly weather variables were also recorded at a weather station located at our research site. Weekly fecal samples were collected from all collared cattle $(n=16)$ to determine botanical composition of diets. Decreasing air temperatures, increasing relative humidity, winds out of the northwest (all of which are associated with heat loss), and increasing short-term thermal stress were associated with a detectable $(P \leq 0.05)$ increase in PJ-woodland preference of PN and NPNL cows. Days to/from calving date was a significant predictor of PJ-woodland preference of PN cows $(P \leq 0.05)$, which showed highest PJ-woodland preference on the day before or immediately after calving date. Preference for PJ woodland by all cows, averaged across the study period, increased with the increasing proportion of days with cold short-term thermal stress $(P<0.01)$ and decreasing availability of open shortgrass forage $(P<0.01)$. PN and NPNL cows exhibited detectably different grazing patterns $(P=0.01)$. PN cows explored smaller areas $(P<0.01)$ and traveled shorter distances $(P=0.053)$ than NPNL counterparts in any given day. Winterfat (Krascheninnikova lanata [Pursh] A. Meeuse \& Smit) was the only plant species analyzed that was detectably more abundant $(P=0.05)$ in NPNL vs. PN diets, particularly during the week surrounding calving in 2005. Our data suggest that PJ woodland with abundant understory can play an important role in providing shelter for nursing or dry cattle during winter, particularly in years when forage availability is scarce.
\end{abstract}

\section{Resumen}

Se condujo un experimento para determinar la importancia de los montes de Pinus edulis y Juniperus monosperma (PJ) en la provisión de reparo para vacas en un sitio en el centro de Nuevo México. Se determinó la posición de 16 vacas, ocho vacas gestantes/lactantes (GL) y ocho vacas secas (S), a intervalos de 5 minutos con GPS. Las vacas pastorearon un mosaico de monte y pastizal abierto de pastos cortos durante fines de invierno y principios de primavera de 2004 y 2005 (en cada año se utilizaron vacas diferentes). Se tomaron mediciones de variables meteorológicas cada hora usando una estación ubicada en nuestro sitio experimental. Se tomaron muestras semanales de fecas de todas las vacas portadoras del GPS $(n=16)$ para determinar la composición botánica de las dietas. Temperaturas del aire decrecientes, incrementos en la humedad relativa ambiente, vientos del NO (todos estos factores están asociados a pérdida de calor), e incrementos de estrés térmico de corto plazo estuvieron asociados con un incremento detectable $(P \leq 0.05)$ de la preferencia por el monte de PJ de vacas GL y S. Días hasta/desde el parto fue un predictor significativo $(P \leq 0.05)$ de preferencia por el monte de PJ de vacas GL, que exhibieron alta preferencia por el monte en el día inmediatamente anterior o posterior al parto. El promedio de preferencia por el monte de PJ de todas las vacas para el período de este experimento aumentó con un incremento en la proporción de días fríos en los que los animales sufrieron estrés térmico de corto plazo $(P \leq 0.01)$ y disponibilidad decreciente de forraje en el pastizal abierto de pastos cortos $(P \leq 0.01)$. Vacas GL y $S$ exhibieron patrones de pastoreo detectablemente diferentes $(P=0.01)$. Las vacas GL exploraron diariamente áreas más pequeñas $(P \leq 0.01)$ y caminaron distancias diarias menores $(P=0.053)$ que las vacas $S$. Krascheninnikovia lanata fue la única especie vegetal analizada que fue detectablemente $(P=0.05)$ mas abundante en dietas de vacas $S$ que en vacas GL, particularmente en la semana próxima a los partos en 2005. Nuestros resultados sugieren que los montes de PJ con abundante estrato herbáceo pueden jugar un papel importante en la provisión de reparo para vacas lactantes o secas, particularmente en años de baja disponibilidad forrajera.

Key Words: diet selection, GPS monitoring, habitat selection, thermal stress, woodlands

This study was funded by the US Dept of Agriculture, Cooperative State Research, Education, and Extension Service Rangeland Ecosystems Project, the New Mexico Agricultural Experiment Station, and the New Mexico State University Corona Range and Livestock Research Center.

Correspondence: Andrés F. Cibils, Dept of Animal and Range Sciences, MSC 3-I, New Mexico State University, Las Cruces, NM 88003, USA. Email: acibils@nmsu.edu

Manuscript received 15 June 2007; manuscript accepted 29 April 2008. 


\section{INTRODUCTION}

Management of piñon-juniper (PJ) woodlands, which occupy more than 30 million ha in the western United States (West 1999), has changed considerably during the recent past. Wholesale tree-clearing practices, common in the mid-20th century, have been gradually replaced by selective thinning operations aimed at supporting the output of multiple woodland resource products (Gottfried and Severson 1994; Brockway et al. 2002; Albert et al. 2004; Landis and Bailey 2005; Miller et al. 2005). Modified woodland vegetation structures that benefit both livestock and native wildlife in the semiarid Southwest require a patchwork of overstory openings within a matrix of denser woodland cover (Gottfried and Pieper 2000, and references therein). These patches, which are increasingly common in the area surrounding our research site in central New Mexico, exhibit contrasting abiotic (microclimate) and biotic (forage) characteristics that provide unique opportunities to study the role of PJ woodland in providing thermal cover for livestock. Investigation of factors that affect daily feeding-site choices by livestock that graze these vegetation mosaics will allow managers to refine current woodland-thinning criteria by explicitly considering livestock foraging behavior and welfare needs.

A number of conceptual models developed over the past $20 \mathrm{yr}$ have sought to explain observed patterns of ungulate response to heterogeneous grazing environments (Senft et al. 1987; Bailey et al. 1996; Provenza et al. 1998; Bailey 2005; Launchbaugh and Howery 2005). Earlier models, such as the one proposed by Senft et al. (1987), assumed that foragerelated variables (interactive factors) were responsible for grazing behavior patterns observed at small to intermediate spatial and temporal scales (patches to plant communities and minutes to days); whereas abiotic (noninteractive) factors, such as climate, topography, and fire, were assumed to influence grazing decisions at the scale of landscapes and seasons. Bailey et al. (1996) later recognized that noninteractive factors (particularly ambient temperatures) influence grazing decisions at the scale of camps (several weeks) and home ranges (months). In a more recent conceptual model, weather is portrayed as influencing grazing decisions at the even smaller scale of feeding sites, defined as the area explored by a cow in 1-4 h (Bailey 2005). Nevertheless, the influence of noninteractive factors on cattle foraging decisions at these smaller spatial and temporal scales has not been widely documented. We predicted that daily variation in late winter to early spring weather conditions (a set of abiotic, noninteractive factors) would have a measurable effect on cattle grazing behavior at intermediate spatial and temporal scales (plant communities and days). Thus, we expected cattle preference for woodlanddominated feeding sites to vary in response to daily weather fluctuations.

Although foraging decisions are constrained by an animal's physiological state (Laca and Demment 1996), most of the conceptual models mentioned above did not consider such effects (but see Provenza et al. 1998). Energy expenditure, activity budgets, and use of sheltered sites by cattle that graze rangeland pastures are all significantly affected by reproductive state (Sprinkle et al. 2000; Bailey et al. 2001; Brosh et al. 2006) and body condition (Olson and Wallander 2002; Tucker et al.
2007). Given that "an animal's behavior depends on its state [and that] the behavior in turn changes the [animal's] state" (Houston 1993, p 11), we predicted that weather would influence preference for PJ-woodland feeding sites of nonpregnant-nonlactating (NPNL) and pregnant or nursing (PN) cows differently, particularly on the days surrounding calving (pregnant cows would exhibit higher preference for PJwoodland feeding sites) and on the days immediately following calving (PN cows' ability to respond to weather factors would be more restricted).

The primary purpose of this study was to describe the relationships between daily variations in plant community preference and changes in weather conditions in relation to the reproductive state of young cows. In addition, we sought to gain insight into the role that PJ woodlands play in providing shelter for cattle during calving in early spring.

\section{MATERIALS AND METHODS}

\section{Study Site}

Our study was conducted at the New Mexico State University Corona Range and Livestock Research Center (CRLRC) in the spring of 2004 and 2005 . The CRLRC (lat $34^{\circ} 15^{\prime} 36^{\prime \prime} \mathrm{N}$, long $\left.105^{\circ} 24^{\prime} 36^{\prime \prime} \mathrm{W}\right)$ has an average elevation of $1900 \mathrm{~m}$ and is located approximately $22.5 \mathrm{~km}$ east of the village of Corona, New Mexico. Mean annual precipitation is $400 \mathrm{~mm}$, most of which occurs in July and August as high-intensity, shortduration, convectional thunderstorms. A number of soil associations are present at this site. Valley floor soils are in the Sampson loam association (0-5\% slope) and are deep, welldrained soils. Gently sloping soils (2-15\% slope), included in the Penistaja-Travessilla, Plack-Dioxice, and Plack-Penistaja associations, tend to be shallow to moderately deep. The Stroupe-Deama association includes steep ( $30-75 \%$ slope) mesa sides and rock outcrops (Soil Conservation Service 1983). Vegetation is composed of perennial short grasses with an overstory of sparse to dense piñon pine (Pinus edulis Engelm.) and one-seed juniper (Juniperus monosperma [Engelm.] Sarg.) woodland. The predominant understory grasses are blue grama (Bouteloua gracilis [Willd. ex Kunth] Lag. ex Griffiths), wolftail (Lycurus phleoides Kunth), threeawns (Aristida spp. L), sideoats grama (B. curtipendula [Michx.] Torr.), and sand dropseed (Sporobolus cryptandrus [Torr.] A. Gray).

Two adjacent pastures, which were partially cleared mechanically of PJ in the 1980s, were used for this study. The first pasture (Horse), was grazed in late winter (from 15 February to 15 March in 2004 and 2005) and had an area of approximately 146 ha consisting of $55 \%$ open shortgrass steppe with interspersed juniper saplings and 45\% PJ woodland. Topography was flat to gently sloping with a low-lying area running laterally through the pasture. There was one drinking water location on the far west end of this pasture, with no other ephemeral water sources. The second pasture (Mesa) was grazed in early spring (from 15 March to 15 April in 2004 and 2005) and had an area of approximately 219 ha, $70 \%$ of which was a lower area that was half open shortgrass steppe and interspersed juniper saplings and half PJ; the remaining $30 \%$ of the pasture was located on a mesa that was covered by open PJ. Because animals had to climb steep slopes $(>60 \%)$ to reach the mesa area, the latter was rarely 
grazed by cattle. There was one permanent drinking water source in the northeast corner of the pasture.

\section{Animals}

Four 4-yr-old, pregnant cows $(\sim 430 \mathrm{~kg})$ and four NPNL cows $(\sim 500 \mathrm{~kg})$ of the same age were monitored in 2004, whereas four pregnant and four NPNL 3-yr-old cows $(\sim 400 \mathrm{~kg}$ and $\sim 465 \mathrm{~kg}$, respectively) were tracked in 2005. Animals were selected based on availability of NPNL cows and proximity to calving date; all animals were familiar with the experimental pastures. Pregnant cows calved from 3 March to 10 March in 2004 and from 1 March to 6 March in 2005, respectively. The cows used were predominantly of Angus breeding with some Hereford and Simmental influence.

Each cow was fitted with a Global Positioning System (GPS) collar (Lotek 3300, Newmarket, ON, Canada) configured to record and store position, temperature, and head up or down readings at 5-min intervals. All collared cows (PN and NPNL) grazed together with a herd of young mother cows (77 in 2004 and 88 in 2005); pastures were moderately stocked (4.5 ha. animal unit $\left.{ }^{-1} \cdot 60 \mathrm{~d}^{-1}\right)$ in both years. Upon entering Mesa pasture, all cattle were gathered and individually fed supplements twice a week at the water. Twice weekly, all collared cows were individually fed; they consumed $3.97 \mathrm{~kg}$ of supplement cubes containing approximately $32 \%$ crude protein, based on wheat middlings (a subproduct that remains after flour is extracted from wheat during milling), cottonseed meal, and feather meal.

\section{Data Collection}

In the first week of March, each year, herbaceous biomass and species composition were estimated using comparative yield and dry weight rank methods (Despain and Smith 1997; Smith and Despain 1997). Eight 50-m transects (four in open shortgrass and four in PJ woodland) were randomly located in Horse pasture, and 10 transects (six in open shortgrass and four in PJwoodland) were located in Mesa pasture. A $0.25-\mathrm{m}^{2}$ quadrat was placed at 2-m intervals along each transect, herbaceous biomass was estimated, and the three most abundant herbaceous species present were recorded. Herbaceous biomass was clipped at 10 -m intervals on each transect. Clipped samples were dried in a forced-air oven at $50^{\circ} \mathrm{C}$ for $24 \mathrm{~h}$, weighed, and used to develop regression equations to estimate herbaceous biomass for each plant community in each pasture.

Weather data were retrieved from the New Mexico Climate Center weather station, located on the CRLRC (elevation $1876 \mathrm{~m}$, lat $34^{\circ} 9^{\prime} 36^{\prime \prime} \mathrm{N}$, long $\left.105^{\circ} 14^{\prime} 24^{\prime \prime} \mathrm{W}\right)$ approximately $3 \mathrm{~km}$ from our research pastures. Weather readings at this station were recorded hourly and uploaded to the Internet daily. Weather variables considered in this study included 1) air temperature $\left({ }^{\circ} \mathrm{C}\right)$; 2) precipitation $(\mathrm{mm})$; 3) relative humidity $(\%) ; 4)$ soil temperature $\left.\left({ }^{\circ} \mathrm{C}\right) ; 5\right)$ solar radiation (langley $\cdot \mathrm{h}^{-1}$ ); 6 ) wind direction (azimuth degrees, where north $=0^{\circ}$, east $=$ $90^{\circ}$, south $=180^{\circ}$, and west $=270^{\circ}$ ); and 7) wind speed $\left(\mathrm{m} \cdot \mathrm{s}^{-1}\right)$. Mean daily wind direction during the period of our study in both years ranged from $86^{\circ}$ to $280^{\circ}$; therefore, we considered it unnecessary to transform our data to account for potential distortions caused by extreme north-northwest or north-northeast winds approaching $0^{\circ}$. Weather variables were used to compute wind chill-corrected air temperatures $\left({ }^{\circ} \mathrm{C}\right)$ and short-term thermal stress $\left(\mathrm{STTS} ;{ }^{\circ} \mathrm{C}\right)$. Wind chill temperatures (WCT) were calculated using an equation developed by Johnson et al. (1987) for cattle with winter coats that have $2 \mathrm{~cm}$ or greater hair length:

$$
\begin{aligned}
& {[\text { WCT }=-1.4109-(0.00334 \times \text { wind speed })} \\
& \left.+(0.995 \times \text { air temperature })-(0.000013 \times \text { wind speed })^{2}\right]
\end{aligned}
$$

Measurement units for wind speed and air temperature in this equation were in kilometers per day and ${ }^{\circ} \mathrm{C}$, respectively. STTS expresses daily deviations from the air temperature to which cattle have presumably become acclimated (Rittenhouse and Senft 1982). Temperature acclimation is a physiological process assumed to occur over a period of approximately 12 consecutive d (Senft and Rittenhouse 1985); hence, daily STTS values reflect the difference between mean air temperature for a given day and the average mean daily temperature of the previous $12 \mathrm{~d}$.

GPS collar data were differentially corrected using reference data from a base station located approximately $100 \mathrm{~km}$ from our site (Albuquerque, New Mexico; lat 34 57'26 ' N, long $\left.106^{\circ} 29^{\prime} 40^{\prime \prime} \mathrm{W}\right)$. Drinking water location and pasture boundary data were recorded using a handheld GPS unit (Thales Mobile Mapper, Santa Clara, CA), with an accuracy of $3 \mathrm{~m}$. Postprocessed collar data were mapped in a geographic information system environment that consisted of a base layer of digital orthophotos of the experimental pastures with overlaying polygons that distinctly showed the boundaries of the pasture and of the PJ woodland (including sparse and dense PJ) and open shortgrass plant communities.

We selected subsets of GPS collar data corresponding to days surrounding calving in Horse pasture, covering 1 March to 17 March (day -7 to day 8 of calving) in 2004 and 27 February to 13 March (day -5 to day 7 of calving) in 2005. We also selected 3-d blocks of weekly GPS data from Mesa pasture covering 23 March to 8 April in 2004 and 29 March to 14 April in 2005. Three-day blocks consisted of location data recorded on Tuesdays, Wednesdays, and Thursdays, which included the days most removed from supplementation events that occurred on Mondays and Fridays.

The spatial response variables for each collared cow were calculated using ArcView 3.3 and 9.0 (Environmental Systems Research Institute 1994, 2004) and included 7 variables: 1) daily distance traveled $(\mathrm{km}) ; 2$ ) daily maximum (straight line) distance traveled from water $(\mathrm{km}) ; 3$ ) daily time spent at water (within $15 \mathrm{~m}$ of water; \%); 4) daily time spent in PJ woodland and dense PJ woodland (\%); 5); daily time spent in PJ woodland during morning (0600-1100 hours; \%); 6) daily time spent in PJ woodland during afternoon (1300-1800 hours; \%); and 7) minimum convex polygon of the area explored in a day (ha). Minimum convex polygons of terrain covered were estimated using Hawth's Analysis Tools for ArcGIS 9.0 (Beyer 2004), whereas Spatial Tools 3.2 for ArcView 3.3 (Hooge 1999) was used to calculate distances traveled and time spent at water.

Because diet composition can be expected to reflect the direct consequences of feeding site-selection decisions, microhistolog- 
ical analysis of fecal grab samples was conducted (Sparks and Malechek 1968). Samples from each collared animal were collected on 19 March, 2 April, and 17 April in 2004 and on 6 March, 18 March, 1 April, and 15 April in $2005(n=56)$. Fecal samples were dried in a forced-air oven at $50^{\circ} \mathrm{C}$ for $48 \mathrm{~h}$, ground through a 1-mm screen in a Wiley mill, and sent to be analyzed for botanical composition (Micro Composition Laboratory, Ft. Collins, CO). Two slides (50 fields each) were read for each fecal sample to compare major diet components ( $\geq 1$ sample with frequency $>15 \%$ ) of PN- and NPNL-collared cows and to study the relationships between diets and plant community use patterns.

\section{Data Analysis}

We developed a preference index computing the ratio between percentage of time spent in PJ woodland and percentage of PJwoodland area available in each pasture. This preference index was used as the main response variable in our analyses of plant community use in relation to weather and animal physiological state. The area covered by mature PJ woodland $(45 \%$ of the area at Horse and approximately $50 \%$ of the grazeable area at Mesa) remained constant throughout our study. Thus, this preference index provided a measure of plant community use relative to its availability in a given pasture. This index assumed that, if animals were neither selecting for nor against a plant community, the time spent in that community should be proportional to its abundance (index $=1$ ). If, on the other hand, animals spent a disproportionately large or small amount of time in a plant community (relative to its abundance), active selection for or against such a community was inferred. Thus, indices $>1$ indicated preference for a given plant community, whereas indices $<1$ were interpreted to indicate the opposite.

The influence of reproductive state and weather variables on daily plant community preference (expressed as PJ-woodland preference) of collared PN and NPNL cows was modeled using PROC MIXED in SAS 9.1 (SAS Institute 2003). Year (2004 or 2005) was treated as the replication unit and was modeled as a random variable using the "random $=$ year $/$ sub $=$ pasture" statement in SAS 9.1 (SAS Institute 2003). Days were modeled as repeated measures within each year using the "repeated day $(y r) / s u b=$ cow ID" statement in SAS 9.1 (SAS Institute 2003). First-order autoregressive covariance structure, which accounts for higher correlation between observations taken on the same subject at closer vs. more distant time intervals (Littell et al. 2006), was the covariance structure that best fit our data and was used in all analyses via the AR(1) option in SAS 9.1 (SAS Institute 2003). Fixed model terms included year, reproductive state of cows (PN vs. NPNL), pasture (Mesa, Horse), day nested within year, and mean daily values of air temperature, soil temperature, solar radiation, relative humidity, precipitation, wind velocity, wind direction, wind chill-corrected temperature, and STTS. A second analysis was conducted, including only PN cows, using the same model structure but including days to calving in addition to all other independent variables listed above.

Selection of models with the subset of independent variables that best fit the structure of our data was achieved using the second-order Akaike Information Criterion for small sample size $\left(\mathrm{AIC}_{c}\right.$; Sugiura 1978) and the Minimum Description Length (MDL; Rissanen 2007) criterion. Bayesian Information Criterion (Schwartz 1978) values, which tend to penalize complexity more than $\mathrm{AIC}_{c}$, were also calculated as a reference but were not used as a criterion to select final models. Model selection was conducted using ALLMIXED2.SAS (Fernandez 2007), a SAS 9.1 (SAS Institute, 2003) macro application, which selected candidate models with $\Delta \mathrm{AIC}_{c} \leq 2$ and $\Delta \mathrm{MDL} \leq 1$, from all possible combinations of fixed effects within a subset of 838 mixed models that contained $\geq 4$ and $\leq 8$ independent variables. Preliminary analyses using simpler regression models suggested that this range of independent variables would minimize chances of overfitting and allow parsimonious representation of our data. Values of $\Delta \mathrm{AIC}_{c}$ and $\triangle \mathrm{MDL}$ were computed as the differences between the actual $\mathrm{AIC}_{c}$ or MDL of a model and the $\mathrm{AIC}_{c}$ or MDL of the model with the lowest value and were used as a measure of the empirical support for the model selected (Burnham and Anderson 2002). Model selection of the subset of PN cow data was conducted using only $\mathrm{AIC}_{c}$. After model selection, parameter estimates of model terms in all candidate models and effects of interactions between categorical (reproductive state, pasture) and continuous (weather variables) terms in models with the smallest $\mathrm{AIC}_{c}$ and MDL values were examined using the PROC MIXED model in SAS 9.1 (SAS Institute 2003) described above.

Despite setting a priori constraints on the number of independent variables, the total number of models evaluated $(n=838)$ exceeded the size of our data set (all cows, $n=400$; PN cows only, $n=200$ ). The uncertainty of models selected with information criterion methods increases significantly in situations where the number of models evaluated is much larger than the number of observations (Burnham and Anderson 2002). In such cases, a large number of models with low $\Delta \mathrm{AIC}_{c}$ are selected and, thus, the $\mathrm{AIC}_{c}$ weights of the best models (which reflect the relative likelihood of the model given the data) approach zero (Burnham and Anderson 2002). This was apparently not the case in our study in which $\mathrm{AIC}_{c}$ and MDL weights of the small number of selected models ranged from 0.15 to 0.64 .

The relationship between average plant community use in each pasture, forage availability, and thermal environment was examined with multiple regression analysis using PROC GLM in SAS 9.1 (SAS Institute 2003). Mean PJ-woodland preference by PN and NPNL cows in Horse and Mesa pastures during 2004 and $2005(n=8)$ was regressed against forage availability in open shortgrass, proportion of days with cold STTS, and the interaction between those predictors. Days with cold STTS were defined as the proportion of days in each pasture with wind chill-corrected temperatures of $\leq 1^{\circ} \mathrm{C}$ and negative STTS values. Because of the low number of samples, significance level for this analysis was set at $P \leq 0.10$.

Discriminant analysis (DA) is frequently used to classify animals into groups on the basis of multiple criteria, such as the selection of diets (Hanley and Hanley 1982, Ortega et al. 1997) or variations in behaviors (Bayley et al. 1997, Darden et al. 2003, Delgado 2007). We used DA to determine whether PN and NPNL cows could be classified into significantly different groups based on their daily use of plant communities and daily activity patterns. PROC DISCRIM of SAS 9.1 (SAS Institute 
Table 1. Mean and ranges of daily weather variables at the Corona Range and Livestock Research Center during days in Horse and Mesa pastures in 2004 and 2005.

\begin{tabular}{|c|c|c|c|c|}
\hline & \multicolumn{2}{|c|}{2004} & \multicolumn{2}{|c|}{2005} \\
\hline & 1-17 March (Horse) & 23 March to 8 April (Mesa) & 27 February to 13 March (Horse) & 29 March to 14 April (Mesa) \\
\hline Air temp $\left({ }^{\circ} \mathrm{C}\right)$ & $6.1(0.2-13.1)$ & $12.1(7.1-16.8)$ & $6.3(1.5-13.5)$ & $8.1(0.81-13.0)$ \\
\hline Daily precipitation (cm) & $0.1(0.0-0.8)$ & $0.2(0.0-0.5)$ & $0.3(0.0-2.3)$ & $0.0(0.0)$ \\
\hline Relative humidity (\%) & $57.9(23.0-93.7)$ & $48.6(22.7-82.1)$ & $49.2(16.7-84.7)$ & $18.2(16.6-21.0)$ \\
\hline Soil temperature $\left({ }^{\circ} \mathrm{C}\right)$ & $8.2(-1$ to 16.6$)$ & $17.2(8.9-21.7)$ & $7.8(1.3-14.1)$ & $9.0(5.4-11.9)$ \\
\hline Solar radiation (langley $\cdot \mathrm{h}^{-1}$ ) & $16.5(7.2-21.0)$ & $19.4(12.1-23.8)$ & $4.0(0.1-20.7)$ & $5.3(0.1-15)$ \\
\hline Wind direction (azimuth ${ }^{\circ}$ ) & $189.7(86.1-280.0)$ & $231.2(156.3-269.6)$ & $217.2(101.4-278.0)$ & $142.9(100.0-179.0)$ \\
\hline Wind speed $\left(m \cdot \mathrm{s}^{-1}\right)$ & $5.8(6.1-22.0)$ & $4.9(8.0-17.8)$ & $5.2(7.1-23.6)$ & $4.9(3.1-21.3)$ \\
\hline Wind chill temp $\left({ }^{\circ} \mathrm{C}\right)$ & $3.0(-2.4$ to 10.0$)$ & $9.2(4.3-13.6)$ & $3.3(-1.5$ to 9.9$)$ & $5.2(-2.5$ to 10.4$)$ \\
\hline STTS $\left({ }^{\circ} \mathrm{C}\right)^{1}$ & $1.9(-2.6$ to 8.7$)$ & $1.4(-2.1$ to 4.6$)$ & $2.0(-1.9$ to 6.7$)$ & $0.2(-4.9$ to 2.6$)$ \\
\hline
\end{tabular}

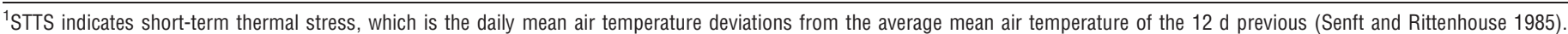

2003) was used to conduct this analysis, which only included the period immediately before and after calving (days in Horse pasture) in 2004 and 2005. Given that both groups of cows (PN, NPNL) had the same number of individuals, it was deemed reasonable to assume equal prior probability of group membership (McGarigal et al. 2000), using the "priors= equal" option in SAS 9.1 (SAS Institute 2003). The predictors included in this analysis were daily distance traveled, time spent at water, maximum daily distance traveled from water, time spent in PJ woodland, time during morning hours spent in PJ woodland, time during afternoon hours spent in PJ woodland, and daily minimum convex polygon of area explored. Variable means for each collared cow $(n=16,8$ in each year) were computed, and all cows were included in a single analysis. The assumption of equal variance-covariance matrices, which is a critical assumption of DA, particularly if used for confirmatory analysis (McGarigal et al. 2000), was tested using the "pooled = test wcov" option in SAS 9.1 (SAS Institute 2003). Cross validation was conducted to determine the error rate of the discriminant function using the "crossvalidate" option in SAS 9.1 (SAS Institute 2003). Multivariate analysis of variance, using Wilks' $\lambda$ as the test statistic, was used to determine whether differences between groups (PN vs. NPNL) were detectable. The significance level for these tests was set at $P \leq 0.05$.

After discrimination of PN and NPNL cows had been completed, stepwise discriminant function analysis was conducted using PROC STEPDISC in SAS 9.1 (SAS Institute 2003). A significance level of $P=0.15$ was used to enter or retain variables in the reduced model (Affifi and Clark 1996). The stepwise analysis was used to identify the predictors with the presumed highest-discriminating power in the full-discriminant function (described above; McGarigal et al. 2000). We then conducted $t$ tests to determine whether the means of variables selected in the stepwise procedure were detectably different for PN and NPNL cows. We used PROC UNIVARIATE and PROC TTEST in SAS 9.1 (SAS Institute 2003) to conduct independent $t$ tests after testing for violations of normality assumptions (Shapiro-Wilk test) and homogeneity of variances (folded $F$ test).

Botanical composition of diets was analyzed using PROC MIXED in SAS 9.1 (SAS Institute 2003). Year (2004 or 2005) was again treated as the replication unit and was modeled as a random variable, whereas weeks were modeled as repeated measures within each year. First-order, autoregressive covariance structure was the covariance structure that best fit our data (unstructured and compound-symmetry covariance structures were also tested) and was used in all analyses via the AR(1) option in SAS 9.1 (SAS Institute 2003). Model terms included year, reproductive state of cows (PN vs. NPNL), and week nested within year. Vegetation composition was similar in both pastures (Horse and Mesa); thus, this factor was excluded from the analyses. The significance level for these tests was set at $P \leq 0.05$. We also conducted correlation analysis to explore the relationship between mean dietary composition of collared animals during weeks 1 and $2(n=16)$ and mean plant community use and activity variables (listed in the previous paragraph) for all collared cows.

\section{RESULTS}

\section{Herbaceous Biomass and Weather Variables}

Herbaceous biomass in Horse pasture was $248 \pm 300 \mathrm{~kg} / \mathrm{ha}$ in the open shortgrass and $272 \pm 128 \mathrm{~kg} / \mathrm{ha}$ in $\mathrm{PJ}$ woodland in 2004 and $357 \pm 94 \mathrm{~kg} / \mathrm{ha}$ in open shortgrass and $355 \pm 108 \mathrm{~kg} /$ ha in PJ woodland in 2005. In Mesa pasture, herbaceous biomass was $400 \pm 99 \mathrm{~kg} / \mathrm{ha}$ in open shortgrass and $112 \pm 69 \mathrm{~kg} / \mathrm{ha}$ in PJ woodland and $840 \pm 70 \mathrm{~kg} / \mathrm{ha}$ in open shortgrass and $365 \pm 43 \mathrm{~kg} / \mathrm{ha}$ in PJ woodland in 2004 and 2005, respectively.

Weather variables for the 2004 and 2005 sampling seasons were similar (Table 1), although 2005 tended to exhibit fewer days with wind chill-corrected air temperatures below freezing, than 2004, during the sampling period surrounding calving in early March (1 d in 2005 vs. 7 d in 2004). Conversely, weather during the second sampling period (April) was warmer and more humid in 2004 vs. 2005 (Table 1).

\section{Plant Community Preference}

PN and NPNL cows spent approximately one third of their time in PJ woodland during late winter in 2004 (means \pm SE; PN: $33 \% \pm 5$; NPNL: $31 \% \pm 4$ ). In 2005, all cows spent considerably less time in PJ woodland during the same period (PN: $14 \% \pm 3$; NPNL: $15 \% \pm 2$ ). As the grazing season progressed, both groups of cows tended to spend an increas- 
Table 2. Sets of predictors that best described the preference for piñon-juniper-dominated feeding sites by pregnant/nursing (PN) and nonpregnant-nonlactating (NPNL) cows, and PN cows alone. Models with Delta Akaike Information Criterion for small sample size $\left(\Delta \mathrm{AIC}_{c}\right) \leq 2$ or Delta Minimum Description-Length $(\triangle \mathrm{MDL}) \leq 1$ were selected as final candidates out of 838 models. Bayesian Information Criterion (BIC) values are shown for reference. Candidate models in bold letters had the lowest $\Delta \mathrm{AIC}_{c}$ or $\Delta \mathrm{MDL}$ and were, therefore, assumed to include the set of predictors that best described the structure of our data.

\begin{tabular}{|c|c|c|c|c|c|}
\hline Model $^{1}$ & $\mathrm{AIC}_{c}$ & $\Delta \mathrm{AIC}_{c}$ & MDL & $\Delta \mathrm{MDL}$ & BIC \\
\hline \multicolumn{6}{|l|}{ PN and NPNL cows } \\
\hline Past - Temp $+\mathbf{R H}+\mathbf{S T T S}$ & 368.28 & 0.00 & & & 353.98 \\
\hline $\mathrm{RH}-\mathrm{Temp}+$ Wind dir $+\mathrm{STTS}$ & 368.58 & 0.29 & & & 354.19 \\
\hline Past - Temp + RH + Wind dir + STTS & & & 177.25 & 0.00 & 351.72 \\
\hline Past - Temp + RH + Wind vel + Wind dir + Soil temp + STTS & & & 177.50 & 0.25 & 352.22 \\
\hline Past - Temp + RH + Wind vel + Soil temp + STTS & & & 177.63 & 0.38 & 352.48 \\
\hline Past - Temp + RH + Wind dir + Soil temp + STTS & & & 177.84 & 0.59 & 352.90 \\
\hline Past - Temp $+\mathrm{RH}+$ Wind vel + Wind dir + STTS & & & 178.18 & 0.93 & 353.60 \\
\hline \multicolumn{6}{|l|}{ PN cows only } \\
\hline Temp - Days to calving + Wind vel - WCF & 218.11 & 0.00 & & & 199.09 \\
\hline Temp $+\mathrm{RH}+$ Wind vel - WCF & 219.21 & 1.10 & & & 200.20 \\
\hline
\end{tabular}

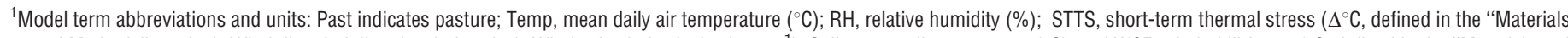

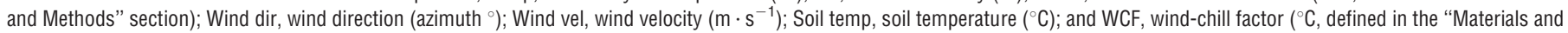
Methods" section).

ingly smaller fraction of their time in PJ woodland in both 2004 (PN: 13\% \pm 3 ; NPNL: 14\% \pm 3 ) and 2005 (PN 9\% \pm 2 ; NPNL: $8 \% \pm 2$ ).

Pasture (Horse or Mesa), decreasing air temperatures, increasing relative humidity, winds out of the northwest (all of which are associated with heat loss), and increasing STTS were the subset of predictors that best explained the variation in PJ woodland preference of PN and NPNL cows (Table 2). Air temperature and relative humidity were the weather variables selected in all seven candidate models, underscoring their detectable influence on day-to-day feeding-site selection patterns of cows (Table 2). STTS was the animal-based indicator of thermal discomfort, which was consistently selected in all candidate models; PJ woodland preference of all cows showed a high degree of sensitivity to STTS in both years, particularly during the colder (earlier) period of the study (Fig. 1). Pasture (Horse or Mesa) was a predictor selected in all but one of the candidate models and, therefore, also appeared to play an important role in PJ-woodland preference patterns of cattle. The fact that cows grazed Horse pasture during the first (and colder) part of the study in both years and grazed Mesa during the latter (warmer) part of the study may explain the importance of this model term as a predictor of PJ-woodland preference of PN and NPNL cows. In effect, an interaction between pasture and air temperature was detected $(P<0.01)$, which indicated that decreasing air temperatures were associated with increasing PJwoodland preference in Horse, but not Mesa, pasture.

Reproductive state was not selected as a predictor in any of the candidate models, suggesting that whether a cow was PN or NPNL had little influence on her preference for PJ woodland. Nonetheless, days to calving was selected in the model that best described PJ-woodland preference of the subset of PN cows (Table 2). Increasing days to or from calving date were associated with decreasing preference for PJ woodland, which peaked for a short time (usually $2 \mathrm{~d}$ or less) around calving date in both years (Fig. 2). Interestingly, wind chill factor, rather than STTS (which takes temperature acclimation into account), was the animal-based thermal-discomfort indicator that was selected in the PN model with lowest $\mathrm{AIC}_{c}$ value (Table 2). Nursing cows may have been slightly (albeit not detectably) more sensitive to short-term thermal changes.

Preference for PJ woodland for all cows, averaged across the study period, increased with increasing proportion of days with cold STTS $(P<0.01)$ and with decreasing open shortgrass forage availability $(P<0.01)$. The interaction between these predictors was marginally detectable $(P=0.11)$ and suggested that the relation between PJ woodland preference and STTS was dependent on forage availability in open shortgrass (Fig. 3).

\section{Daily Activity Patterns of PN vs. NPNL Cows}

Cows were discriminated into two significantly different groups (PN vs. NPNL, $P<0.01$; Table 3 ) based on their daily activity patterns and use of plant communities. The discriminant function was able to correctly classify all PN and all but one NPNL cows in the cross-validation procedure. The stepwise discriminant procedure selected distance traveled and minimum convex polygon of the area explored in a day as the two variables with most discriminating influence (Table 3). PN cows explored detectably smaller areas $(P<0.01)$ and traveled shorter distances $(P=0.053)$ than NPNL cows on any given day (Table 3).

\section{Diet Selection}

We detected differences between years (2004 vs. 2005) in percentage of warm season grasses (Aristida spp., $P=0.01$; Bouteloua gracilis, $P=0.02$ ) and cool season subshrub (winterfat [Krascheninnikovia lanata (Pursh) A. Meeuse \& Smit], $P=0.02$ ) in cattle diets, which may have been the result of an additional (earlier) sampling date in 2005 (Fig. 4). Diets of PN and NPNL cows contained less Aristida spp. (mean \pm SEM; 2004: $9.2 \pm 2.6 ; 2005: 5.0 \pm 1.1)$ and Bouteloua gracilis (2004: 58.6 $\pm 2.7 ; 2005: 46.9 \pm 6.6)$ and more K. lanata (2004: $5.2 \pm 2.7 ; 2005: 16.1 \pm 8.4)$ in 2005 vs. 2004 . Proportion of all plant species (those mentioned above in addition to Stipa 

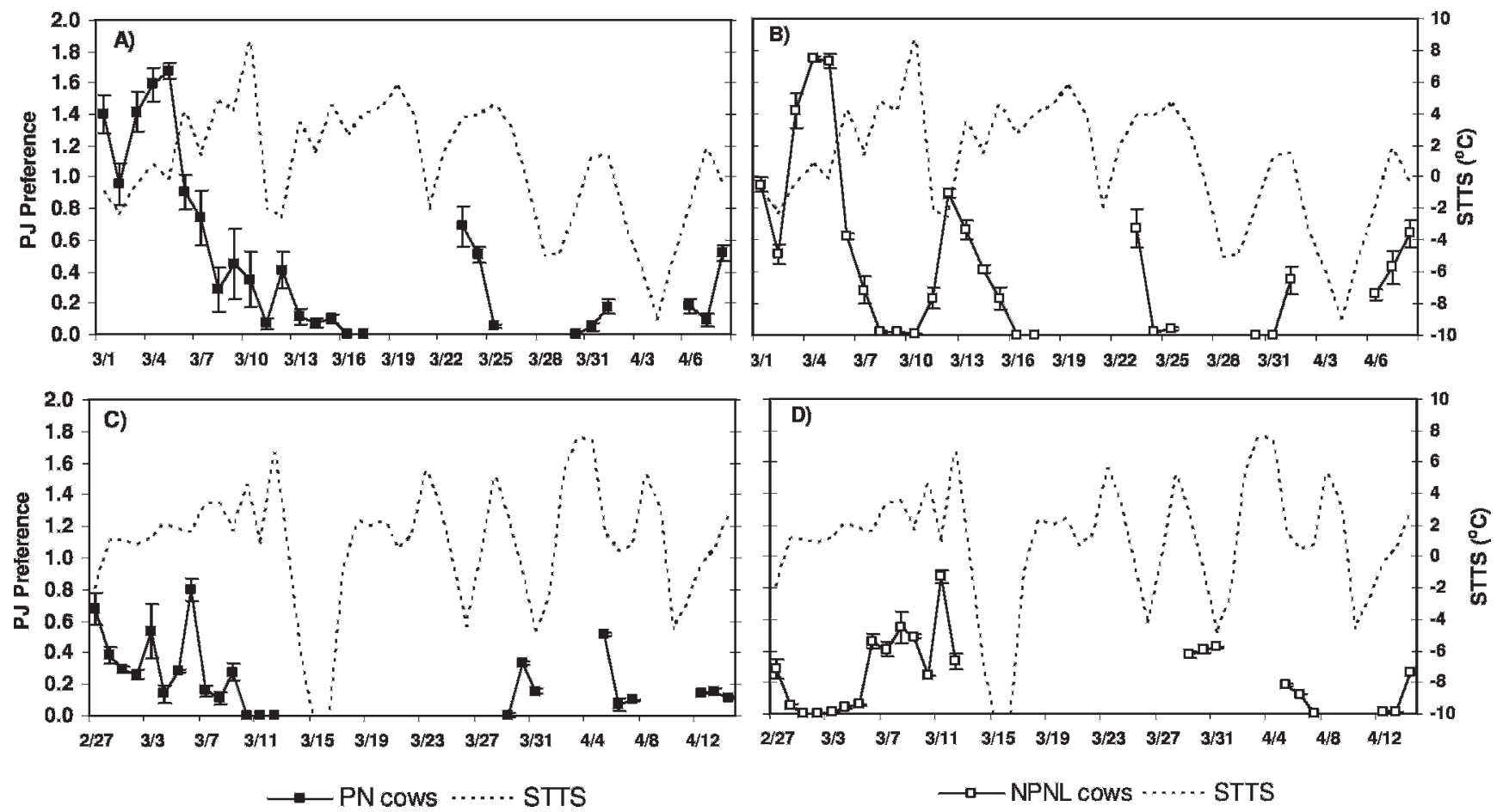

Figure 1. Daily piñon-juniper (PJ) woodland preference (solid lines) of $\mathbf{A}, \mathbf{C}$, pregnant/nursing (PN) cows and $\mathbf{B}, \mathbf{D}$, nonpregnant-nonlactating cows (NPNL) during the A, B, 2004 and C, D, 2005 seasons in relation to short term thermal stress (STTS; broken lines). STTS expresses daily deviations from the air temperature to which cattle have presumably become acclimated (Rittenhouse and Senft 1985). Bars indicate standard errors of the mean.
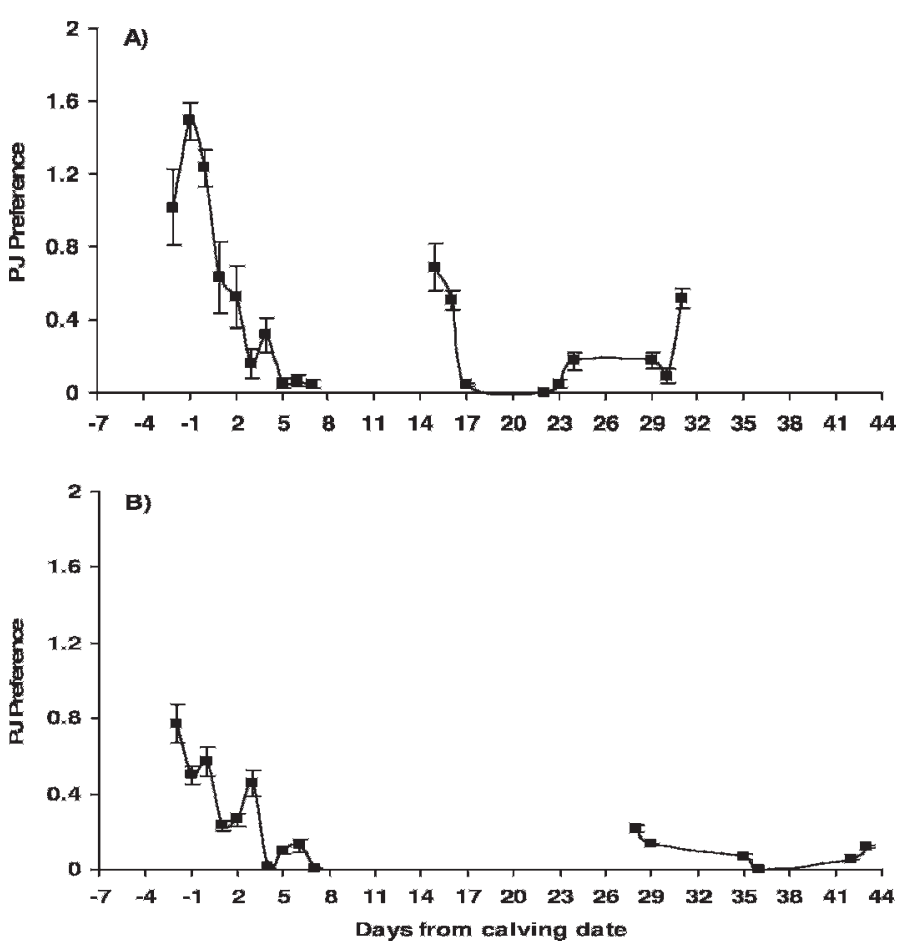

Figure 2. Daily piñon-juniper (PJ) woodland preference of pregnant/ nursing cows shown in relation to calving date in $\mathbf{A}, 2004$ and $\mathbf{B}, 2005$ Bars indicate standard errors of the mean.

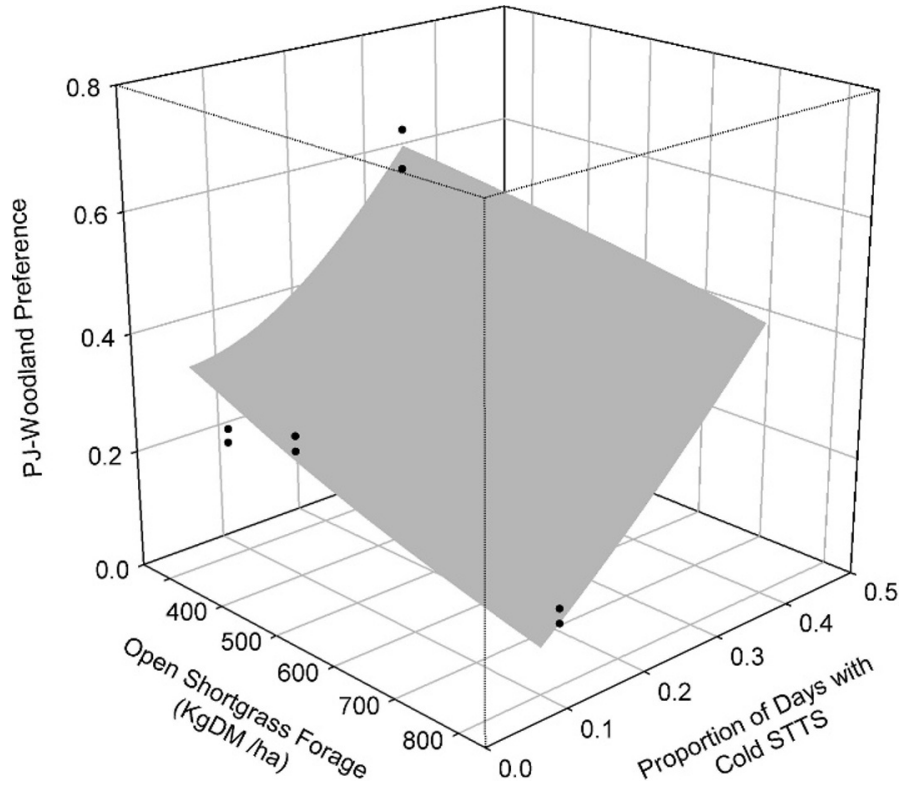

Figure 3. Interaction $(P=0.11)$ between forage availability of open shortgrass areas and the proportion of cold days $\left(1^{\circ} \mathrm{C}\right.$ wind-chill factor), in which animals were subjected to short term thermal stress (STTS), and its effect on preference for piñon-juniper (PJ) woodland feeding sites. Mean PJ-woodland preference of pregnant/nursing cows and nonpregnant-nonlactating cows for Horse and Mesa pastures in 2004 and 2005 were used to develop this figure $(n=8)$. Data points used to construct the response surface are shown. 
Table 3. Daily means (SE) for discriminant function analysis variables used to classify nonpregnant-nonlactating (NPNL) cows and pregnant/ nursing (PN) cows in Horse pasture (days surrounding calving date) during 2004 and 2005. Boldface rows include reduced sets of predictors selected in the stepwise procedure; $t$ statistic and corresponding $P$ values for predictor mean comparison are shown. Wilks' $\lambda, F$ statistic, and $P$ values from the multivariate analysis of variance for the complete models are shown below.

\begin{tabular}{|c|c|c|c|c|}
\hline Predictor $^{1}$ & NPNL cows & PN cows & $t$ & $P$ \\
\hline Distance traveled (km) & $5.9(0.3)$ & $5.3(0.2)$ & 2.11 & 0.053 \\
\hline Time at water (\%) & $4.2(0.9)$ & $2.9(0.7)$ & & \\
\hline Max. daily distance to water (km) & $1.6(0.1)$ & $1.3(0.1)$ & & \\
\hline Time spent in PJ woodland (\%) & $22.7(3.2)$ & $23.8(4.6)$ & & \\
\hline A.M. time spent in PJ woodland (\%) & $23.5(2.4)$ & $22.3(5.3)$ & & \\
\hline P.M. time spent in PJ woodland (\%) & $12.7(2.5)$ & $16.6(4.0)$ & & \\
\hline Minimum convex polygon area (ha) & $54.8(3.2)$ & $30.4(2.1)$ & 6.47 & $<0.001$ \\
\hline Wilks' $\lambda$ & 0.215 & & & \\
\hline$F_{6,9}$ & 5.490 & & & \\
\hline$P$ & 0.012 & & & \\
\hline
\end{tabular}

${ }^{1} \mathrm{PJ}$ indicates piñon-juniper.

neomexicana [Thurb. ex J. M. Coult.] Barkworth and Optuntia spp. L.) in cattle diets changed significantly as the season progressed, which possibly reflected changes in phenological stage.

Differences in diet selection among PN and NPNL cows occurred during the first part of the study period; thus, we, possibly, only captured the effects of animal state in 2005. Frequency of $K$. lanata was detectably higher $(P=0.05)$ in NPNL vs. PN diets (mean \pm SEM; PN: $6.2 \pm 2.0$; NPNL: $16.7 \pm 9.6$ ), which was driven by opposite patterns of $B$. gracilis and $K$. lanata selection than occurred early in the same season in 2005 (Fig. 4).

Increasing time spent in PJ woodland was associated with increasing warm season grasses $(r=0.76 ; P<0.01)$ and Stipa neomexicana $(r=0.65 ; P=0.01)$ but decreasing $K$. lanata $(r=-0.69 ; P<0.01)$ and Opuntia spp. $(r=0.50 ; P=0.06)$ in cattle diets.

\section{DISCUSSION}

Weather conditions were significant predictors of day-to-day changes in plant community preference (PJ woodland vs. open shortgrass) of cattle in both years. Physiological state had only transient effects on PJ-woodland preference, which occurred on the days surrounding calving. Overall, daily changes in thermal conditions resulted in similar PJ-woodland preference patterns
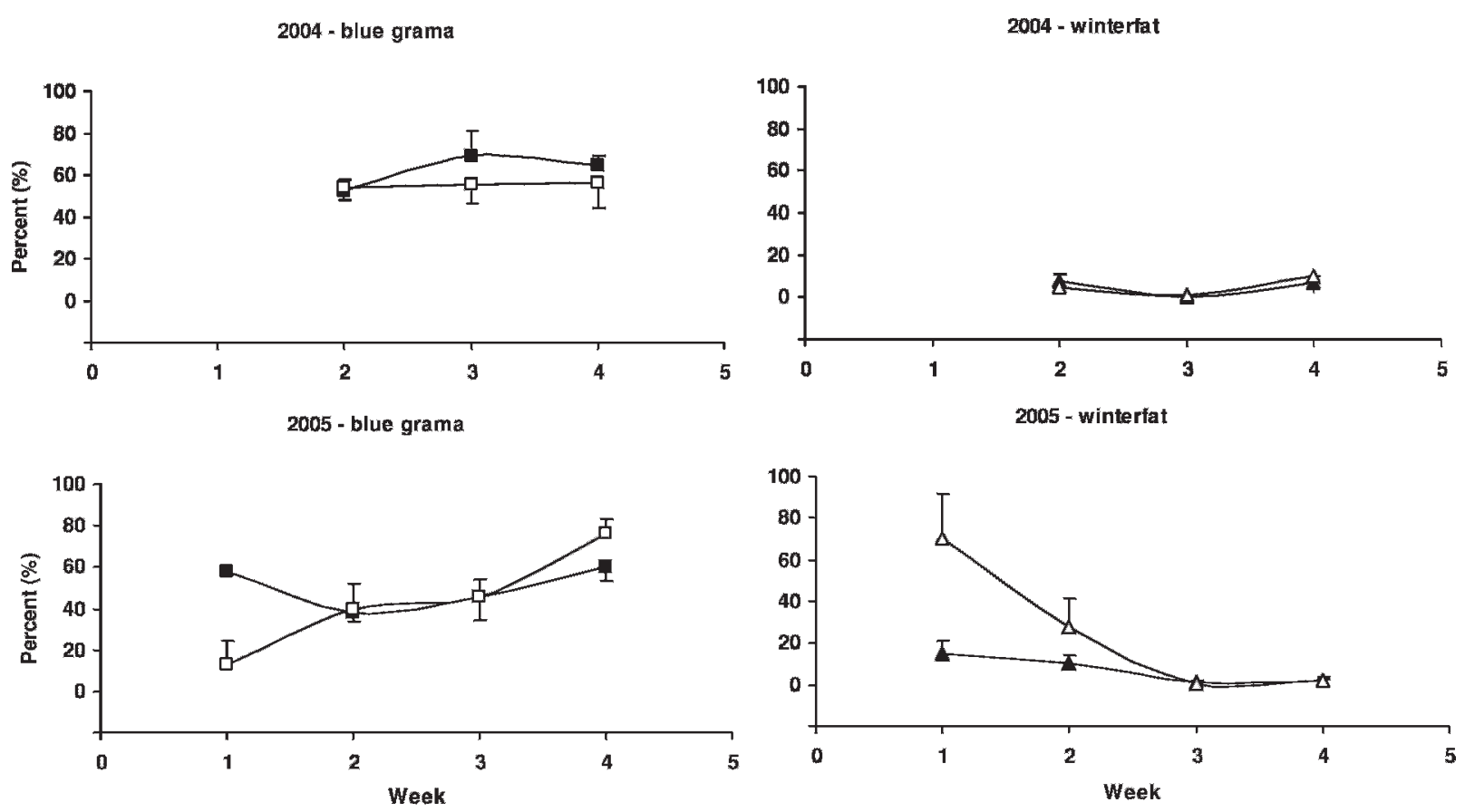

Figure 4. Frequency of blue grama (Bouteloua gracilis) and winterfat (Krascheninnikovia lanata) in diets of pregnant/nursing cows (PN; full symbols) and nonpregnant-nonlactating cows (NPNL; empty symbols). Fecal samples from four PN and four NPNL collared cows were collected on 19 March, 2 April, and 17 April in 2004 and on 6 March, 18 March, 1 April, and 15 April in 2005 ( $n=56$ ). Bars indicate standard errors of the mean. 
for PN and NPNL cows. Because PN and NPNL cows were members of a single herd, it is conceivable that behavior of one group may occasionally have been influenced by the other, although NPNL cows were usually observed grazing on their own (C. M. Black Rubio, unpublished data). PJ-woodland feeding sites appeared to play an important role in providing thermal shelter to both PN and NPNL cows. Previous studies conducted close to our research site during summer and early fall had shown that heifers preferred open or sparse PJ woodland compared with dense PJ woodland and open grassland (Rogers 1996); however, the influence of weather and reproductive state of cattle were not explicitly considered in that study.

STTS was a significant predictor in all models of cattle preference for PJ woodland in this study. Senft and Rittenhouse (1985), who developed the STTS concept, predicted decreasing daily forage intake in response to STTS during winter. Later studies by Dunn et al. (1988) and Beverlin et al. (1989) tested this prediction and found that daily feeding time and daily forage intake of cows grazing Montana winter ranges did not decrease in response to STTS. Although these authors did not document cattle feeding-site choices in relation to pasture microclimates, Beverlin et al. (1989) recognized that "choice of foraging locations may alter in response to thermal stressors" (p. 82), a statement that our data appear to support. Cattle possibly respond to STTS by first adjusting their behavior so as to maintain thermal comfort and adequate levels of intake. To do this, they can either maximize exposure to solar radiation while grazing (Keren and Olson 2006) or seek sheltered feeding sites, as occurred in this and other studies (Senft et al. 1983; Senft et al. 1985; Houseal and Olson 1995; Beaver and Olson 1997). If no sheltered feeding sites are available, cattle may adopt other energy-saving strategies, such as lying down to minimize exposure to winds (Olson and Wallander 2002; Tucker et al. 2007), which should eventually result in a sharp decrease in grazing time as documented by Malechek and Smith (1976) and Adams et al. (1986). The availability of sheltered feeding sites for cattle, such as islands of PJ woodland with adequate understory, could, therefore, be critical to maintaining levels of adequate forage intake during periods of moderate thermal stress.

Most studies addressing the influence of winter temperatures on cattle foraging behavior were conducted at higher latitudes with considerably lower mean daily temperatures than those recorded during our study (Malechek and Smith 1976; Adams et al. 1986; Beverlin et al. 1989; Houseal and Olson 1995; Olson and Wallander 2002). Minimum ambient temperatures during all sampling periods in our study were well above the lower critical temperature for cattle (approximately $-20^{\circ} \mathrm{C}$; Yousef 1985). Nevertheless, ambient conditions were significant predictors of day-to-day cattle feeding-site choices. Thermoregulation-driven feeding behaviors appeared to occur at ambient temperatures considered to be well within a cow's thermoneutral zone (Yousef 1985). Our data suggest that noninteractive factors, such as ambient temperatures, may play a larger role than previously recognized in day-to-day plant community selection by livestock.

The relation between factors that intervene in the grazingdecision process (interactive vs. noninteractive) has not been adequately addressed since Smith (1988), who proposed a hierarchy of animal needs. According to that author, thermoregulation needs take precedence over forage-driven grazing decisions. Davison and Neufeld (2005) reported that construction of artificial shade structures to alleviate summer heat stress was not sufficient to lure cattle away from riparian plant communities. Harris et al. (2002), on the other hand, reported that when temperatures drop below freezing in the San Joaquin Valley in California, cattle move to warmer (sheltered) sites, forgoing areas with feed supplements. Our data (Fig. 3) suggest that the interplay between weather and forage-related factors may exhibit a threshold-like behavior. When forage production was less than $250 \mathrm{~kg} / \mathrm{ha}$ (in Horse pasture during 2004), cattle showed a high preference for PJ-dominated (sheltered) plant communities on cold days when animals were exposed to STTS. Under such conditions, cows spent more than $90 \%$ of their day in wooded areas, forgoing higher-quality forages, such as K. lanata, which was only available in open shortgrass areas. When, on the other hand, forage availability in the grassland plant community was higher (in 2005, during a rainy spring), cattle avoided PJ areas even on days surrounding calving date (PN cows) or cold days that should have induced STTS. Animals with higher nutritional state (as was possibly the case with cows in 2005) exhibit higher metabolic rates and, therefore, demand less cold-induced heat production than animals with lower nutritional states (possibly collared cows in 2004; Ingram and Dauncey 1985). Thus, cattle in our study appeared to move between "energy conserving" and "energy acquiring" modes in the 2004 and 2005 seasons, respectively. This behavioral pattern supports the Olson and Wallander (2002, p. 491) observation that "during winter, cattle behavior is a tradeoff between maximizing energy gain (thermal and food) and minimizing energy loss (thermal and metabolic)."

Previous studies addressing the impact of physiological state on foraging behavior of cattle frequently focused on forage intake (Arnold 1985) or individual functional response (bite rate, bite mass, time grazing) to changes in forage conditions (Gibb et al. 1999; Sprinkle et al. 2000). The influence of an animal's state on its position relative to the herd or the grazing resources (including plant communities) has received less attention (Laca and Demment 1996). Our study showed that, although PN and NPNL cows responded similarly to daily changes in thermal conditions, mother cows explored smaller areas and traveled shorter distances than NPNL cows on any given day. Thus, PN cows tended to exhibit more spatially concentrated grazing patterns, which may have constrained their diet selection ability, particularly on the days surrounding calving. Diets of NPNL cows had higher amounts of winterfat (high quality, yet more dispersed, forage) than diets of their PN counterparts. Such differences, however, were only evident in our first sampling date in 2005, which coincided with the end of calving of collared PN cows. Collectively, our data suggest that a cow's physiological state affected grazing patterns but exerted short-lived variation in diet and feeding site selection, which occurred on the days surrounding calving.

\section{MANAGEMENT IMPLICATIONS}

Day-to-day weather conditions were significant predictors of animal foraging decisions at the scale of days and plant 
communities. A more detailed description of the thermal environment beneath woodland canopy and in open grassland areas will be needed to develop better predictive models of plant community preference. PJ woodlands appear to play an important role in providing shelter for cattle, particularly in years when forage availability is in short supply. Further research is needed to determine the size and density of woodland patches that would provide the optimal mix of forage and shelter conditions. Our study suggests that a mosaic of wooded and open areas may be the plant community mix that could best provide for forage and thermoregulation needs of cattle at these sites.

\section{ACKNOWLEDGMENTS}

We are indebted to Shad Cox and Michael Rubio for assistance in conducting this study. Jenny Gomez, Amber Helmus, and Kyle Jackson helped with vegetation surveys in the field. We are thankful to Dean Anderson, Derek Bailey, and Jon Boren who provided valuable comments and discussion on earlier versions of this manuscript. One anonymous reviewer and the associate editor (E. Laca) suggested changes that greatly improved this manuscript.

\section{LITERATURE CITED}

Adams, D. C., T. C. Nelsen, W. L. Reynolds, and B. W. Knapp. 1986. Winter grazing activity and forage intake of range cows in the northern Great Plains. Journal of Animal Science 62:1240-1246.

AfiFl, A., AND V. ClaRk. 1996. Computer aided multivariate analysis. 3rd ed. London, United Kingdom: Chapman \& Hall. 455 p.

Albert, S., N. Luna, R. Jensen, and L. Livingston. 2004. Restoring biodiversity to piñon-juniper woodlands. Ecological Restoration 22:18-23.

ArnoLd, G. W. 1985. Regulation of forage intake. In: R. J. Hudson and R. G. White [EDS.]. Bioenergetics of wild herbivores. Boca Raton, FL, USA: CRC Press. p. 81-102.

Balley, D. W. 2005. Identification and creation of optimum habitat conditions for livestock. Rangeland Ecology and Management 58:109-118.

Balley, D. W., J. E. Gross, E. A. Laca, L. R. Rittenhouse, M. B. Coughenour, D. M. Swift, And P. L. Sims. 1996. Mechanisms that result in large herbivore grazing distribution patterns. Journal of Range Management 49:386-400.

Balley, D. W., D. D. Kress, D. C. Anderson, D. L. Boss, and E. T. Miller. 2001. Relationship between terrain use and performance of beef cows grazing foothill rangeland. Journal of Animal Science 79:1883-1891.

Bayley, M., E. Baartup, and P. Buerregaard. 1997. Woodhouse locomotor behavior in the assessment of clean and contaminated field sites. Environmental Toxicology and Chemistry 16:2309-2314.

Beaver, J. M., and B. E. OLson. 1997. Winter range use by cattle of different ages in southwestern Montana. Applied Animal Behaviour Science 51:1-13.

Beverlin, S. K., K. M. Havstad, E. L. Ayers, and M. K. Petersen. 1989. Forage intake responses to winter cold exposure of free-ranging beef cows. Applied Animal Behaviour Science 23:75-85.

BEYER, H. L. 2004. Hawth's analysis tools for ArcGIS [computer program]. Available at: http://www.spatialecology.com/htools. Accessed 1 July 2005.

Brockway, D. G., R. G. Gatewood, and R. B. Paris. 2002. Restoring grassland savannas from degraded pinyon-juniper woodlands: effects of mechanical overstory reduction and slash treatment alternatives. Journal of Environmental Management 64:179-197.

Brosh, A., Z. Henkin, E. D. Ungar, A. Dolev, A. Orlov, Y. Yehuda, and Y. Aharoni. 2006. Energy cost of cows' grazing activity: use of the heart rate method and the Global Positioning System for direct field estimation. Journal of Animal Science 84:1951-1967.
Burnham, K. P., and D. R. Anderson. 2002. Model selection and multimodel inference: A practical information-theoretic approach. 2nd ed. New York, NY, USA: Springer.

Darden, S. K., T. Dabelsteen, and S. B. Pedersen. 2003. A potential tool for swift fox (Vulpes velox) conservation: individuality of long-range barking sequences. Journal of Mammalogy 84:1417-1427.

Davison, J. C., and J. D. Naufeld. 2005. Can shade structures help riparian areas? Rangelands 27:24-30.

Delgado, R. A., JR. 2007. Geographic variation in the long calls of male orangutans (Pongo spp.). Ethology 113:487-498.

Despain, D. W., and E. L. Smith. 1997. The comparative yield method for estimating range production. In: G. B. Ruyle [ED.]. Some methods for monitoring rangelands. Tucson, AZ, USA: Arizona Cooperative Extension Publication 190043. p. 27-48.

Dunn, R. W., K. M. Havstad, and E. L. Ayers. 1988. Grazing behavior responses of rangeland beef cows to winter ambient temperatures and age. Applied Animal Behaviour Science 21:201-207.

Environmental Systems Research Institute. 1994. ArcView 3.3 [computer program]. Redlands, CA, USA: ESRI.

Environmental Systems Research Institute. 2004. ArcMap 9.0 [computer program]. Redlands, CA, USA: ESRI.

Fernandez, G. 2007. Model selection in PROC MIXED—a user-friendly SAS ${ }^{\circledR}$ macro application. SAS Global Forum Paper 191-2007. Available at: http://www2.sas. com/proceedings/forum2007/191-2007.pdf. Accessed 20 December 2007.

GibB, M. J., C. A. Huckle, R. Nuthall, and A. J. Rook. 1999. The effect of physiological state (lactating or dry) and sward surface height on grazing behaviour and intake by dairy cows. Applied Animal Behaviour Science 63:269-287.

Gottfried, G. J., and R. D. Pieper. 2000. Pinyon-juniper rangelands. In: R. Jemison and C. Raish [EDS.]. Livestock management in the American Southwest: ecology, society and economics. Amsterdam, Netherlands: Elsevier Science. p. 153-211.

Gottriled, G. T., and K. E. Severson. 1994. Managing pinyon-juniper woodlands. Rangelands 16:234-236.

Hanley, T. A., and K. A. Hanley. 1982. Food resource partitioning by sympatric ungulates on Great Basin Rangeland. Journal of Range Management 35:152-158.

Harris, N. R., D. E. Johnson, M. R. George, and N. K. McDougald. 2002. The effect of topography, vegetation, and weather on cattle distribution at the San Joaquin Experimental Range, California. In: R. B. Standiford, D. McCreary, and K. L. Purcell [eds.]. Proceedings of the Fifth Symposium on Oak Woodlands: Oaks in California's Challenging Landscape; 22-25 October 2001; San Diego, CA, USA. Albany, CA, USA: Pacific Southwest Research Station, Forest Service, US Dept of Agriculture General Technical Report PSW-GTR-184. p. 53-56.

Hooge, P. N. 1999. Spatial Tools 3.2 for ArcView 3.3 [computer program]. Available at: http://www.absc.usgs.gov/glba/gistools. Accessed 15 July 2005.

Houseal, G. A., and B. E. OLson. 1995. Cattle use of microclimates on a northern latitude winter range. Canadian Journal of Animal Science 75:501-507.

Houston, A. I. 1993. The importance of state. In: R. N. Hughes [ED.]. Diet selection: an interdisciplinary approach to foraging behaviour. Oxford, United Kingdom: Blackwell Scientific Publications. p. 10-31.

InGRAM, D. L., AND M. J. DaunceY. 1985. Thermoregulatory behavior. In: M. K. Yousef [ED.]. Stress physiology in livestock. Volume 1. Boca Raton, FL, USA: CRC Press. p. 97-108.

Johnson, M. E., W. C. Russell, and J. D. Hanson. 1987. Effect of environment on forage intake of grazing steers: a model. Nutrition Reports International 36:1081-1089.

Keren, E. N., And B. E. OLson. 2006. Thermal balance of cattle grazing winter range: model application. Journal of Animal Science 84:1238-1247.

LaCA, E. A., and M. W. Demment. 1996. Foraging strategies of grazing animals. In: J. Hodgson and A. W. Illus [EDS.]. The ecology and management of grazing systems. Oxon, United Kingdom: CAB International. p. 137-158.

LAndis, A. G., AND J. D. Balley. 2005. Reconstruction of age structure and spatial arrangement of piñon-juniper woodlands and savannas of Anderson Mesa, Northern Arizona. Forest Ecology and Management 204:221-236. 
LaunchBaugh, K. L., and L. D. Howery. 2005. Understanding landscape use patterns of livestock as a consequence of foraging behavior. Rangeland Ecology and Management 58:99-108.

Littell, R. C., G. A. Milliken, W. W. Stroup, R. D. Wolfinger, and 0. Schabenberger. 2006. SAS for mixed models. 2nd ed. Cary, NC, USA: SAS Institute. $840 \mathrm{p}$.

MalecheK, J. C., AND B. M. Smith. 1976. Behavior of range cows in response to winter weather. Journal of Range Management 29:9-12.

McGarigal, K., S. Cushman, and S. StafFord. 2000. Multivariate statistics for wildlife and ecology research. New York, NY, USA: Springer. 312 p.

Miller, R. F., J. D. Bates, T. J. Svejcar, F. B. Pierson, and L. E. Eddleman. 2005. Biology, ecology, and management of western juniper. Corvallis, OR, USA Agricultural Experiment Station, Oregon State University, Technical Bulletin 152. $77 \mathrm{p}$.

Olson, B. E., and R. T. Wallander. 2002. Influence of winter weather and shelter on activity patterns of beef cows. Canadian Journal of Animal Science 82:491-500

Ortega, I. M., S. Soltero-Gadea, F. C. Bryant, and D. L. Drawe. 1997. Evaluating grazing strategies for cattle: deer and cattle food partitioning. Journal of Range Management 50:622-630.

Provenza, F. D., J. J. Villalba, C. D. Cheney, and S. J. Werner. 1998. Selforganization of foraging behaviour: from simplicity to complexity without goals. Nutrition Research Reviews 11:199-222.

RISSANEN, J. 2007. Information and complexity in statistical modeling. New York, NY, USA: Springer. $144 \mathrm{p}$.

Rittenhouse, L. H., and R. L. Senft. 1982. Effects of daily weather fluctuations on the grazing behavior of cattle. In: Proceedings-Western Section American Society of Animal Science Volume 33; 7-9 July 1982; Las Cruces, NM, USA. Savoy, IL, USA: ASAS. p. 305-307.

Rogers, L. B. 1996. Habitat preference of cattle grazing grassland interspersed with varying densities of Piñon-Juniper woodlands [thesis]. Las Cruces, NM, USA: New Mexico State University. $84 \mathrm{p}$.

SAS InSTITUTE. 2003. Statistical analysis system Version 9.1 [computer program]. Raleigh, NC, USA: SAS Institute Inc.

SchwarTZ, G. 1978. Estimating the dimension of a model. Annals of Statistics 6:461-464.

Senft, R. L., M. B. Coughenour, D. W. Balley, L. R. Rittenhouse, O. E. Sala, and D. M. SWIFt. 1987. Large herbivore foraging and ecological hierarchies. BioScience 37:789-799.
Senft, R. L., and L. R. Rittenhouse. 1985. A model of thermal acclimation in cattle. Journal of Animal Science 61:297-306.

Senft, R. L., L. R. Rittenhouse, and R. G. Woodmansee. 1983. The use of regression models to predict spatial patterns of cattle behavior. Journal of Range Management 36:553-557.

Senft, R. L., L. R. Rittenhouse, and R. G. Woodmansee. 1985. Factors influencing patterns of cattle grazing behavior on shortgrass steppe. Journal of Range Management 38:82-87.

Smith, E. L., And D. W. Despain. 1997. The dry-weight rank method of estimating plant species composition. In: G. B. Ruyle [ED.]. Some methods for monitoring rangelands. Tucson, AZ, USA: Arizona Cooperative Extension Publication 190043 p. 49-62.

Soll Conservation Service. 1983. Soil survey of Lincoln County area, New Mexico. Washington, DC, USA: US Dept of Agriculture.

Sparks, D. E., And J. C. MalecheK. 1968. Estimating percentage dry weight in diets using a microscopic technique. Journal of Range Management 21:264-265.

Sprinkle, J. E., J. W. Holloway, B. G. Warrington, W. C. Ellis, J. W. Stuth, T. D. A. Forbes, And L. W. Greene. 2000. Digesta kinetics, energy intake, grazing behavior, and body temperature of grazing beef cattle differing in adaptation to heat. Journal of Animal Science 78:1608-1624.

StAFFORD-SMITH, M. S. 1988. Modeling: three approaches to predicting how herbivore impact is distributed in rangelands. Las Cruces, NM, USA: New Mexico Agricultural Experiment Station, New Mexico State University, Research Report 628. 56 p.

SugluRA, N. 1978. Further analysis of the data by Akaike's information criterion and the finite corrections. Communications in Statistics, Theory and Methods A7:13-26.

Tucker, C. B., A. R. Rogers, G. A. Verkerk, P. E. Kendall, J. R. Webster, and L. R. MatThews. 2007. Effects of shelter and body condition on the behaviour and physiology of dairy cattle in winter. Applied Animal Behaviour Science 105:1-13

WEST, N. E. 1999. Juniper-piñon savannas and woodlands of western North America. In: R. C. Anderson, J. S. Fralish, and J. M. Baskin [EDs.]. Savannas, barrens, and rock outcrop plant communities of North America. New York, NY, USA: Cambridge University Press. p. 288-308.

Yousef, M. K. 1985. Thermoneutral zone. In: M. K. Yousef [ED.]. Stress physiology in livestock. Volume 1. Boca Raton, FL, USA: CRC Press. p. 67-74. 